\title{
GROWTH RESPONSES AND ACCUMULATION OF HEAVY METALS BY FUNGUS AGARICUS BISPORUS
}

\author{
F. Mohammadhasani ${ }^{1 *}$, A. Ahmadimoghadam ${ }^{1}$, Z. Asrar ${ }^{1}$ and S. Z. Mohammadi ${ }^{2}$ \\ ${ }^{1}$ Department of Biology, Faculty of Science, Shahid Bahonar University of Kerman \\ Post Code 76169-14111, Kerman, Iran; *E-mail: Fereshtehmhasani@yahoo.com \\ ${ }^{2}$ Department of Chemistry, Payame Noor University, Tehran, Iran
}

(Received 21 June, 2015; Accepted 26 August, 2015)

\begin{abstract}
Ectomycorrhizal fungi are able to form symbiotic associations with tree roots, and therefore, plants gain different benefits. On metal-contaminated soils, these fungi may improve plant fitness through an enhanced nutrition or by reducing toxicity of the metals. Agaricus bisporus, an edible fungus has been noted to grow in large numbers under Pistacia vera plantations in orchards of Kerman, Iran, indicating that it may form ectomycorrhiza with the tree. This research describes the responses of this fungus to heavy metals in solid and liquid MMN media. The fungus was grown in vitro in liquid and solid cultures for 3 weeks on five different concentrations $(0,15,30,45,60 \mathrm{ppm})$ of five heavy metals $(\mathrm{Cu}, \mathrm{Zn}, \mathrm{Ni}, \mathrm{Co}$, $\mathrm{Mn})$ as sulphate and the effect of these metal on radial growth, biomass production and metal content of fungal biomass were determined. The result showed there was a strong variation in metal tolerance, so that Agaricus bisporus was more tolerant to Mn than other metals, while the reverse was true for $\mathrm{Ni}$, so that the fungus had an increased growth in the presence of low concentrations of $\mathrm{Co}, \mathrm{Mn}$, and $\mathrm{Zn}$, but Ni greatly inhibited increase in biomass and colony diameter even at concentrations as low as $15 \mathrm{mg} / \mathrm{l}$.
\end{abstract}

Key words: Agaricus bisporus, ectomycorrhizal fungus, heavy metals, Pistacia vera

\section{INTRODUCTION}

Environmental contamination with heavy metals has increased over the years. The soil microflora and fauna can be negatively influenced by these contaminations due to the processes of mining, smelting, processing and manufacturing metals and their sub-products (Colpaert 2008, Rühling and Söderström 1990).

Exposure to heavy metals, whether of natural origin, such as metalliferous rocks, or of anthropogenic activity origin, such as pollutions, may be toxic for soil organisms. The degree of toxicity depends mainly on the metallic ele- 
ments and their bioavailability in the soil. Metal bioavailability is a function of abiotic factors, such as metal concentration, humidity and soil $\mathrm{pH}$ value, but also depends on biotic factors, such as the presence of metal-liberating soil bacteria and their existence in the form of fertilisers containing high levels of these metals (Hartley-Whitaker et al. 2000a, b). Various metals, e.g. Zn, $\mathrm{Cu}$ and $\mathrm{Mn}$, are essential for plants at low concentrations, but become toxic at higher concentrations. Some metals are not essential for the development of living organisms and are toxic even at very low concentrations, e.g. $\mathrm{Hg}, \mathrm{Cd}$, $\mathrm{Pb}$ (Trevors et al. 1986).

Mycorrhizal associations between fungi and roots of host plants in metal contaminated soils is an important relationship that plays a vital role in plant tolerance to heavy metals by their accumulation (Adriaensen et al. 2003, Hartley-Whitaker et al. 2000a, b. Marschner et al. 1996). Ectomycorrhizas (ECM) and Arbuscular Mycorrhizas (AM) are the two most common mycorrhizal associations in plants. Mycorrhizal fungi participate in crucial symbiotic relationships with plants that grow on contaminated sites, and alleviate metal toxicity for their host plants (Godbold et al. 1998, Jentschke and Godbold 2000, Schützendübel and Polle 2002).

Many ectomycorrhizal fungi show resistance to heavy metals, and together with the use of plants can be useful in bioremediation of contaminated areas ((Dixon 1988, Jones and Hutchinson 1988, Marschner et al. 1996). An opinion was even presented that the abilities of trees and other perennial plants to grow in polluted habitats is only possible due to mycorrhization of their roots (Crane et al. 2013, Wilkinson and Dickinson 1995).

Many investigations have been carried out on the ability of the fungus in accumulating heavy metals. On metal-contaminated soils, ECM fungi may improve plant fitness through an enhanced nutrition or by reducing toxicity of the metals. Although amelioration of metal phytotoxicity by ECM fungi has been widely demonstrated, the tolerance mechanisms involved are not well understood (Crane et al. 2013, Carrillo-González and González-Chávez 2012).

The aim of the present study was to assess the tolerance rate of the fungus Agaricus bisporus grown on pure solid and liquid culture media exposed to different levels of heavy metals, like $\mathrm{Cu}, \mathrm{Ni}, \mathrm{Co}, \mathrm{Mn}$ and $\mathrm{Zn}$.

\section{MATERIALS AND METHODS}

\section{Growing the fungus on solid culture media}

The fungus was collected beneath the canopies of pistachio trees in Kerman, Iran and was grown on solid MMN (Modified Melin Norkrans) media $\left(\mathrm{KH}_{2} \mathrm{PO}_{4}(500 \mathrm{mg} / \mathrm{l}),\left(\mathrm{NH}_{4}\right)_{2} \mathrm{HPO}_{4}(250 \mathrm{mg} / \mathrm{l}), \mathrm{CaCl}_{2}(50 \mathrm{mg} / \mathrm{l}), \mathrm{NaCl}(25 \mathrm{mg} / \mathrm{l})\right.$, $\mathrm{MgSO}_{4} \cdot 7 \mathrm{H}_{2} \mathrm{O}(150 \mathrm{mg} / \mathrm{l})$, thiamine hydrochloride $(0.1 \mathrm{mg} / \mathrm{l})$, and $\mathrm{FeCl}_{3} \cdot 6 \mathrm{H}_{2} \mathrm{O}$ 
$(1 \mathrm{mg} / \mathrm{l})$ to which $10 \mathrm{~g}$ glucose and $12 \mathrm{~g}$ agar was added. Stock cultures containing $\mathrm{Cu}, \mathrm{Ni}, \mathrm{Co}, \mathrm{Mn}$ and $\mathrm{Zn}$ as sulphate salts in 15, 30, 45, 60 ppm concentrations of each metal were prepared.

MMN-agar media were dispensed in a series of Petri dishes, each series containing one of the elements at concentrations of $0,15,30,45$ and 60 ppm. Mycelial disks of $11 \mathrm{~mm}$ diameter were cut with a flame-sterilised cork borer from the edge of the growing colonies of the fungus and used as inocula for test plates containing various concentrations of heavy metals. Plates were wrapped in aluminium foil and maintained at $20-25^{\circ} \mathrm{C}$ until the mycelium on the control dishes (Zero concentration of metals) reached at $7.0 \mathrm{~cm}$. The radial growth of the mycelia was measured at their widest diameter. The diameter of the original culture $(1.1 \mathrm{~cm})$ was subtracted from the final measurement. Three Petri dishes were employed at each concentration for every metal. The data were compared statistically by using SPSS.

\section{Biomass production in liquid culture media containing heavy metals}

Fifteen $\mathrm{ml}$ of liquid MMN medium (without agar), containing 0, 15, 30, 45 and $60 \mathrm{ppm}$ of $\mathrm{Zn}, \mathrm{Cu}, \mathrm{Ni}, \mathrm{Co}$ and $\mathrm{Mn}$ as sulphate were poured in 100-ml conical flasks. The $\mathrm{pH}$ of the media was adjusted to 5.5 except in the case of the media containing $\mathrm{Cu}$, which was adjusted to 4.5 , to avoid its precipitation.

Each flask was inoculated with two 7-mm agar plugs cut from the edge of an actively growing colony precultivated on MMN-agar. The liquid stationary cultivation proceeded at $28{ }^{\circ} \mathrm{C}$ in the dark. Three replicates of each concentration were employed. After 21 days, mycelia were harvested, washed with distilled water and dried at $105^{\circ} \mathrm{C}$ and weighed subsequently. The mass of agar plugs used as inoculums were subtracted.

\section{Measurement of metals in fungal biomass}

Triplicate samples of colonies were digested in $5 \mathrm{ml} \mathrm{HNO}_{3}$ plus $1 \mathrm{ml} \mathrm{HF}$ solutions for heavy metal analysis. The digested fungal samples were analysed for $\mathrm{Cu}, \mathrm{Co}, \mathrm{Zn}, \mathrm{Ni}$ and $\mathrm{Mn}$ contents of the mycelia. A Sens AA GBC atomic absorption spectrophotometer (Dandenog, Australia) equipped with deuterium background correction and air-acetylene burner was used for absorbance measurements of nickel, cobalt, copper, zinc and manganese.

\section{Experimental design and statistical data analysis}

The experimental design was completely randomised with 5 treatments, one cultivar and three replications per treatment. The experimental design 
was a completely randomised design. Data were analysed by using one-way analysis of variance (ANOVA). Differences between means were considered significant at confidence level of $\mathrm{P} \leq 0.05$. All statistical analyses were done using the software SPSS package, version 18.0. The Duncan test analysis was done to determine the significant difference between treatments.

\section{RESULTS}

\section{Colony diameter of the fungus}

The results showed as the concentrations of the metals increased in solid culture media, the diameter of the colonies of the fungus decreased significantly compared to the control. Decline of the diameter was statistically significant in all treatments of $\mathrm{Mn}, \mathrm{Co}, \mathrm{Cu}$ and $\mathrm{Ni}$ compared to the control. Lower significant growth was observed also in Zn treatment only at $60 \mathrm{ppm}$. The null effect of $\mathrm{Ni}$ on the growth of the fungus was more severe than $\mathrm{Cu}$ and $\mathrm{Co}$, where $15 \mathrm{mg} / \mathrm{l} \mathrm{Ni}$ caused cessation the growth and it did not grow on treatments of $45 \mathrm{mg} / \mathrm{l} \mathrm{Cu}$ and $60 \mathrm{mg} / \mathrm{l} \mathrm{Co} \mathrm{(Table} 1$ ).

\section{Mycelial dry weights}

The results of the measurement of mycelia dry weights of the fungus in the liquid culture media illustrate an inverse relationship between dry mass and metal concentrations in high concentrations of metals, but as shown in Table 2 the low concentration of $\mathrm{Mn}^{2+}$ up to $15 \mathrm{mg} / \mathrm{l}$ in liquid media caused significant increase of the mycelial dry weight of the vegetative hyphae (Table 2).

Table 1

Fungal colony diameters (cm) of Agaricus bisporus grown on MMN solid culture media containing five different concentrations of $\mathrm{Zn}, \mathrm{Mn}, \mathrm{Co}, \mathrm{Cu}, \mathrm{Ni}$. Each data is a mean of three replicates \pm SE. Data with similar letters are not significantly different at $95 \%$ confidence limit. The absence of data indicates negligible mycelial colony diameter.

\begin{tabular}{cccccc}
\hline Metal treatment $(\mathrm{mg} / \mathrm{l})$ & $\mathrm{Zn}$ & $\mathrm{Mn}$ & $\mathrm{Co}$ & $\mathrm{Cu}$ & $\mathrm{Ni}$ \\
\hline Control & $7 \pm 0.00 \mathrm{ab}$ & $6.8 \pm 0.11 \mathrm{a}$ & $6.7 \pm 0.17 \mathrm{a}$ & $7 \pm 0.11 \mathrm{a}$ & $6.9 \pm 0.11 \mathrm{a}$ \\
15 & $5.1 \pm 0.44 \mathrm{~b}$ & $4.8 \pm 0.83 \mathrm{ab}$ & $3.1 \pm 0.24 \mathrm{~b}$ & $2.9 \pm 0.058 \mathrm{~b}$ & $0.0 \pm 0.00 \mathrm{~b}$ \\
30 & $5.3 \pm 0.19 \mathrm{~b}$ & $3.7 \pm 0.17 \mathrm{~b}$ & $2.8 \pm 0.47 \mathrm{~b}$ & $2.3 \pm 0.7 \mathrm{~b}$ & $0.0 \pm 0.00 \mathrm{~b}$ \\
45 & $4.8 \pm 1.9 \mathrm{ab}$ & $3.6 \pm 1.19 \mathrm{~b}$ & $2.3 \pm 0.32 \mathrm{~b}$ & $0.0 \pm 0.00 \mathrm{c}$ & $0.0 \pm 0.00 \mathrm{~b}$ \\
60 & $3.9 \pm 1.00 \mathrm{a}$ & $3.8 \pm 0.31 \mathrm{~b}$ & $0.0 \pm 0.00 \mathrm{c}$ & $0.0 \pm 0.00 \mathrm{c}$ & $0.0 \pm 0.00 \mathrm{~b}$ \\
\hline
\end{tabular}




\section{Table 2}

Mycelial dry weights (mg) of Agaricus bisporus grown in liquid MMN culture media containing five different concentrations of $\mathrm{Zn}, \mathrm{Mn}, \mathrm{Co}, \mathrm{Cu}, \mathrm{Ni}$. Each data is a mean of three replicates \pm SE. Data with similar letters are not significantly different at $95 \%$ confident limit.

\begin{tabular}{cccccc}
\hline Treatment $(\mathrm{mg} / \mathrm{l})$ & $\mathrm{Zn}$ & $\mathrm{Mn}$ & $\mathrm{Co}$ & $\mathrm{Cu}$ & $\mathrm{Ni}$ \\
\hline Control & $0.07 \pm 0.02 \mathrm{ab}$ & $0.07 \pm 0.02 \mathrm{~b}$ & $0.07 \pm 0.02 \mathrm{a}$ & $0.07 \pm 0.02 \mathrm{a}$ & $0.07 \pm 0.02 \mathrm{a}$ \\
15 & $0.07 \pm 0.01 \mathrm{ab}$ & $0.12 \pm 0.01 \mathrm{a}$ & $0.06 \pm 0.01 \mathrm{a}$ & $0.06 \pm 0.01 \mathrm{a}$ & $0.00 \pm 0.00 \mathrm{~b}$ \\
30 & $0.11 \pm 0.03 \mathrm{a}$ & $0.08 \pm 0.01 \mathrm{ab}$ & $0.06 \pm 0.01 \mathrm{a}$ & $0.05 \pm 0.01 \mathrm{a}$ & $0.00 \pm 0.00 \mathrm{~b}$ \\
45 & $0.04 \pm 0.002 \mathrm{ab}$ & $0.08 \pm 0.01 \mathrm{ab}$ & $0.04 \pm 0.005 \mathrm{a}$ & $0.00 \mathrm{~b}$ & $0.00 \pm 0.00 \mathrm{~b}$ \\
60 & $0.03 \pm 0.003 \mathrm{~b}$ & $0.06 \pm 0.008 \mathrm{~b}$ & $0.0 \pm 0.00 \mathrm{~b}$ & $0.00 \mathrm{~b}$ & $0.00 \pm 0.00 \mathrm{~b}$ \\
\hline
\end{tabular}

Heavy metals accumulation in fungal tissues

The results of metal contents of mycelial measurement show that $\mathrm{Zn}$ did not accumulate in the fungi significantly, but Mn content of the mycelia increased slightly up to treatment $45 \mathrm{ppm}$, but highly increased at treatment 60 $\mathrm{ppm}$. The fungus did not absorb Ni from any treatments and accumulation of $\mathrm{Co}$ and $\mathrm{Cu}$ were low at lower concentrations, but did not absorb these metals at high concentrations.

The results of the effect of various concentrations of heavy metals on the accumulation these metals in mycelium were shown that with increase in the concentrations these heavy metals in liquid medium, the amount of metals in mycelium were increased, too, so that in about $60 \mathrm{mg} / \mathrm{l} \mathrm{Mn}^{2+}$ was significant to control (Table 3).

Table 3

Metal contents (mg/g Dw) of Agaricus bisporus grown in vitro for 4 weeks in liquid MMN media containing five different concentrations of the metals. Each data is a mean of three replicates \pm SE. Data with similar letters are not significantly different at $95 \%$ confident limit. The absence of data indicates lack of growth of fungus.

\begin{tabular}{cccccc}
\hline Treatment $(\mathrm{mg} / \mathrm{l})$ & $\mathrm{Zn}$ & $\mathrm{Mn}$ & $\mathrm{Co}$ & $\mathrm{Cu}$ & $\mathrm{Ni}$ \\
\hline Control & $0.31 \pm 0.15 \mathrm{ab}$ & $0.08 \pm 0.02 \mathrm{~b}$ & $0.0 \pm 0.00 \mathrm{a}$ & $0.39 \pm 0.12 \mathrm{a}$ & - \\
15 & $0.19 \pm 0.02 \mathrm{~b}$ & $0.27 \pm 0.03 \mathrm{~b}$ & $0.08 \pm 0.001 \mathrm{a}$ & $0.41 \pm 0.07 \mathrm{a}$ & - \\
30 & $0.18 \pm 0.03 \mathrm{~b}$ & $0.59 \pm 0.14 \mathrm{~b}$ & $0.13 \pm 0.005 \mathrm{a}$ & $0.44 \pm 0.07 \mathrm{a}$ & - \\
45 & $0.30 \pm 0.02 \mathrm{ab}$ & $0.92 \pm 0.27 \mathrm{~b}$ & $0.24 \pm 0.003 \mathrm{a}$ & - & - \\
60 & $0.52 \pm 0.04 \mathrm{a}$ & $3.84 \pm 1.49 \mathrm{a}$ & - & - & - \\
\hline
\end{tabular}




\section{DISCUSSION}

Ectomycorrhizal fungi are essential contributors to mineral nutrient uptake by woody plants, and can play an important role in protecting host trees from stresses, such as heavy metals (Smith and Read 1997).

They may be quite diverse and show considerable metal specificity since large differences in response to metals have been observed, both between fungal species and to different metals within a species (Carrillo-González and González-Chávez 2012, Hartley et al. 1997, Huttermann et al. 1999).

In this study Agaricus bisporus was exposed to five heavy metal cations, $\mathrm{Cu}(\mathrm{II}), \mathrm{Co}(\mathrm{II}), \mathrm{Zn}(\mathrm{II}), \mathrm{Mn}(\mathrm{II})$ and $\mathrm{Ni}(\mathrm{II})$. We attempted to assess the toxicity of these heavy metals to this species by studying their radial growth rate on solid media and growth of biomass in liquid media, and to evaluate biosorption of metals by the species in liquid cultures. This study demonstrated for the first time a variety in growth responses of Agaricus bisporus to heavy metal concentrations. It has been also demonstrated that this fungus accumulated some heavy metals from the environment in axenic culture. Our study revealed that Agaricus bisporus is sensitive to $\mathrm{Ni}$ and $\mathrm{Cu}$ cations in vitro. Differences were found in ability to withstand increasing concentrations of various metals. Nickel arrested growth at lower concentrations than other metals. Copper arrested growth of fungus at $45 \mathrm{mg} / \mathrm{l}$ and the growth of fungus was ceased at $60 \mathrm{mg} / \mathrm{l}$ of cobalt.

Inhibition of growth by one metal at low concentrations did not preclude tolerance to high concentrations of another metal. Tam (1995) showed considerable variation between the ability of five ectomycorrhizal fungi to grow in a culture with a range of nine different heavy metals. This is also in broad concordance with our findings.

In this research there was a strong variation in metal tolerance, so that Agaricus bisporus was more tolerant to $\mathrm{Mn}$, than other metals, while the reverse was true for Ni tolerance.

Interspecific variations have been demonstrated in a number of studies of axenically culture ectomycorrhizal fungi. In one study all isolates of Paxillus involutus were less tolerant to $\mathrm{Zn}$, than any of those of Amanita muscaria (Brown and Wilkins 1985) and also, it was demonstrated that while radial growth of a Suillus bovinus isolate was inhibited by $91 \%$ when exposed to 0.5 ppm cadmium, while Paxillus involutus and Rhizopogon subcaerulescens were only inhibited by approximately 26 and 28\%, respectively (Kim et al. 2004). Also, four isolates of $C$. geophilum demonstrated a range of sensitivities to nickel (Goncalves et al. 2007). A similar response was observed for Cu: Paxillus involutus and Laccaria laccata grew at $2.5 \mathrm{ppm} \mathrm{Cu}$, whereas the concentration had to be decreased 10-fold before any growth of Scleroderma citrinum 
occurred (Howe et al. 1997). Laccaria proxima appeared to be less sensitive to $\mathrm{Ni}$, than Scleroderma avidum (Jones and Hutchinson 1988), and Suillus granulatus had a Cd-E50 value 1,500 times higher, than that of $S$. variegatus (Hartley et al. 1997) and Suillus bovinus, S. luteus and S. variegatus isolates were strongly inhibited by $\mathrm{Ni}$ (Blaudez et al. 2000).

In growth studies on agar and liquid culture, Laccaria laccata proved to be sensitive at $10 \mathrm{ppm}$ to $\mathrm{Cu}$ and $\mathrm{Al}$, but not to $\mathrm{Zn}$ (Jones and Muehlchen 1994). The same study revealed high tolerance of Thelephora terrestris to $\mathrm{Cu}$ (500 ppm) and Zn (1,000 ppm). A liquid culture study indicated that Hymenogaster spp., Scleroderma spp. and Pisolithus tinctorius were able to withstand high concentrations of Al, Fe, Cu and Zn. Naturally; all this has implication for the selection of appropriate ectomycorrhizal fungi for use in remedial plantings on contaminated sites (Tam 1995).

Investigations on the response of the fungus to toxic metals, especially where it is in association with pistachio trees, are carrying out here in Kerman, Iran where the fungus grows at sites beneath the pistachio trees.

Acknowledgement - The authors wish to thank Payame Noor University for support of this work.

\section{REFERENCES}

Adriaensen, K., van der Lelie, D., Van Laere, A., Vangronsveld, J. and Colpaert, J. V. (2003): A Zn-adapted fungus protects pines from Zn stress. - New Phytol. 161: 549-555. http://dx.doi.org/10.1046/j.1469-8137.2003.00941.x

Blaudez, D., Jacob, C., Turnau, K., Colpaert, J. V., Ahonen-Jonnarth, U., Finlay, R., Botton, B. and Chalot, M. (2000): Differential responses of ectomycorrhizal fungi to heavy metals in vitro. - Mycol. Res. 104: 1366-1371. http://dx.doi.org/10.1017/s0953756200003166

Brown, M. T. and Wilkins, D. A. (1985): Zinc tolerance of mycorrhizal Betula. - New Phytol. 99: 101-106. http://dx.doi.org/10.1111/j.1469-8137.1985.tb03640.x

Carrillo-González, R. and González-Chávez, A. (2012): Tolerance to and accumulation of cadmium by the mycelium of the fungi Scleroderma citrinum and Pisolithus tinctorius. - Biol. Trace Elem. Res. 146: 388-395. http://dx.doi.org/10.1007/s12011-011-9267-7

Colpaert, J. V. (2008): Heavy metal pollution and genetic adaptations in ectomycorrhizal fungi: stress in yeast and filamentous fungi. - Br. Mycol. Soc. Symp. Ser. 27: 157-173. http://dx.doi.org/10.1016/s0275-0287(08)80053-7

Crane, S., Dighton, J. and Barkay, T. (2013): Growth responses to and accumulation of mercury by ectomycorrhizal fungi. - Fungal Biol. 114: 873-880. http://dx.doi.org/10.1016/j. funbio.2010.08.004

Dixon, R. K. (1988): Response of ectomycorrhizal Quercus rubra to soil cadmium, nickel, and lead. - Soil Biol. Biochem. 20(4): 555-559.

Gadd, G. M. (1993): Interactions of fungi with toxic metals. - New Phytol. 124: 25-60. 
Gadd, G. M. (2007): Geomycology: biogeochemical transformations of rocks, minerals, metals and radionuclides by fungi, bioweathering and bioremediation. - Mycol. Res. 111: 3-49. http://dx.doi.org/10.1016/j.mycres.2006.12.001

Galli, U., Schuepp, H. and Brunold, C. (1994): Heavy metal binding by mycorrhizal fungi. Physiol. Plant. 92: 364-368. http://dx.doi.org/10.1111/j.1399-3054.1994.tb05349.x

Godbold, D. L., Jentschke, G., Winter, S. and Marschner, P. (1998): Ectomycorrhizas and amelioration of metal stress in forest trees. - Chemosphere 36: 757-762. http://dx.doi. org/10.1016/s0045-6535(97)10120-5

Goncalves, S. C., Portugal, A., Goncalves, M. T., Vieira, R., Martins-Loucao, M. A. and Freitas, H. (2007): Genetic diversity and differential in vitro responses to Ni in Cenococcum geophilum isolates from serpentine soils in Portugal. - Mycorrhiza 17: 677-686. http://dx.doi.org/10.1007/s00572-007-0145-2

Hall, J. L. (2002): Cellular mechanisms for heavy metal detoxification and tolerance. - J. Exp. Bot. 53: 1-11. http://dx.doi.org/10.1093/jexbot/53.366.1

Hartley, J., Cairney, J. W. G., Sanders, F. E. and Meharg, A. A. (1997): Toxic interactions of metal ions $\left(\mathrm{Cd}^{2+}, \mathrm{Pb}^{2+}, \mathrm{Zn}^{2+}\right.$, and $\left.\mathrm{Sb}^{3-}\right)$ on in vitro biomass production of ectomycorrhizal fungi. - New Phytol. 137: 551-562. http://dx.doi.org/10.1046/j.1469-8137.1997.00835.x

Hartley-Whitaker, J., Cairney, J. W. G. and Meharg, A. A. (2000a): Sensitivity to Cd or Zn of host and symbiont of ectomycorrhizal Pinus sylvestris L. (Scots pine) seedlings. Plant and Soil 218: 31-42.

Hartley-Whitaker, J., Cairney, J. W. G. and Meharg, A. A. (2000b): Toxic effects of cadmium and $\mathrm{Zn}$ on ectomycorrhizal colonization of Scots pine (Pinus sylvestris L.) from soil inoculum. - Env. Toxicol. Chem. 19: 694-699. http://dx.doi.org/10.1897/15515028(2000)019<C0694:teocaz>E2.3.co;2

Howe, R., Evans, R. L. and Ketteridge, S. W. (1997): Copper binding proteins in ectomycorrhizal fungi. - New Phytol. 135: 123-131. http://dx.doi.org/10.1046/j.14698137.1997.00622.x

Huang, Y. and Tao, S. (2001): Excessive $\mathrm{Cu}$ and $\mathrm{Zn}$ affecting on distribution of the metals and activities of glycolytic and nitrogen incorporating key enzymes in mycelia of ectomycorrhizal fungi Suillus bovinus. - J. Env. Sci. 13: 337-341.

Huttermann, A., Arudini, I. and Godbold, D. L. (1999): Metal pollution and forest decline. - In: Prasad, M. N. V. and Hagemeyer, J. (eds): Heavy metal stress in plants: from molecules to ecosystems. Springer-Verlag, Berlin, $401 \mathrm{pp}$.

Jentschke, G. and Godbold, D. L. (2000): Metal toxicity and ectomycorrhizas. - Physiol. Plant. 109: 107-116. http://dx.doi.org/10.1034/j.1399-3054.2000.100201.x

Jones, D. and Muehlchen, A. (1994): Effects of the potentially toxic metals, aluminium, zinc and copper on ectomycorrhizal fungi. - J. Env. Sci. Health, Part A: Env. Sci. Engineer. 29: 949-966. http://dx.doi.org/10.1080/10934529409376086

Jones, M. D. and Hutchinson, T. C. (1988): The effects of nickel and copper on the axenic growth of ectomycorrhizal fungi. - Can. J. Bot. 66: 119-124. http://dx.doi.org/10.1139/ b88-018

Kim, C.-G., Power, S. A. and Bell, J. N. B. (2004): Effects of cadmium on radial growth and dry mass production of ectomycorrhizal fungi. - Korean J. Ecol. 27: 301-306. http:// dx.doi.org/10.5141/jefb.2004.27.5.301

Krupa, P. (1997): Inhibition of selected heavy metals translocation through mycorrhizal fungi and process dependence on the fungal symbiont. - Polish J. Env. Studies 6: 35-38. 
Leyval, C., Turnau, K. and Haselwandter, K. (1997): Effect of heavy metal pollution on mycorrhizal colonization and function: physiological, ecological and applied aspects. - Mycorrhiza 7: 139-153. http://dx.doi.org/10.1007/s005720050174

Marschner, P., Godbold, D. L. and Jentschke, G. (1996): Dynamics of lead accumulation in mycorrhizal and non-mycorrhizal Norway spruce (Picea abies (L.) Karst.). - Plant and Soil 178: 239-245. http://dx.doi.org/10.1007/bf00011589

Rühling, A. and Söderström, B. (1990): Changes in fruitbody production of mycorrhizal and litter decomposing macromycetes in heavy metal polluted coniferous forest in North Sweden. - Water, Air, Soil Poll. 49: 375-387. http://dx.doi.org/10.1007/bf00507077

Schützendübel, A. and Polle, A. (2002): Plant response to abiotic stresses: heavy metal-induced oxidative stress and protection by mycorrhization. - J. Exp. Bot. 53: 1351-1365. http://dx.doi.org/10.1093/jexbot/53.372.1351

Smith, S. E. and Read, D. J. (1997): Mycorrhizal symbiosis, 2nd ed. - Academic Press, San Diego.

Tam, P. C. F. (1995): Heavy metal tolerance by ectomycorrhizal fungi and metal amelioration by Pisolithus tinctorius. - Mycorrhiza 5: 181-187. http://dx.doi.org/10.1007/ bf00203335

Trevors, J. T., Stratton, G. W. and Gadd, G. M. (1986): Cadmium transport resistance and toxicity in bacteria, algae and fungi. - Can. J. Microbiol. 32: 447-464. http://dx.doi. org/10.1139/m86-085

Tüzen, M., Özdemir, M. and Demirbaş, A. (1998): Heavy metal bioaccumulation by cultivated Agaricus bisporus from artificially enriched substrates. - Z. Lebensm. Forsch. A. 206: 417-419. http://dx.doi.org/10.1007/s002170050285

Wilkinson, D. M. and Dickinson, N. M. (1995): Metal resistance in trees: the role of mycorrhizae. - Oikos 72: 298-300. http://dx.doi.org/10.2307/3546233 
